\title{
Marzena Sylwia Kruk
}

Uniwersytet Marii Curie-Skłodowskiej w Lublinie

\section{Innowacje społeczne odpowiedzią na lokalne problemy współczesnego społeczeństwa}

STRESZCZENIE Współczesne społeczeństwo w Polsce coraz bardziej zdaje sobie sprawę z tego, że jest również odpowiedzialne za życie gospodarcze i społeczne, szczególnie na poziomie lokalnym. Społeczeństwo obywatelskie nie jest tylko biernym podmiotem usług, lecz także obserwatorem i twórcą. Innowacje społeczne, których głównym celem jest odpowiedź na problemy społeczne, dają możliwości wykorzystania potencjału, jaki tkwi w społeczeństwie obywatelskim. Innowacje społeczne docierają tam, gdzie działania rządowe czy ustawowe nie docierają i nie spełniają swoich funkcji. Innowacje społeczne mają wiele wartości dodatnich, które często trudno określić w wartościach liczbowych. Budowanie partnerstw międzysektorowych, zacieśnianie więzi lokalnych, integracja to tylko niektóre z dodatkowych rezultatów, jakie przynosi wspólna realizacji innowacji społecznych. Wielowymiarowe efekty tego typu innowacji, a przede wszystkim w budowaniu kapitału społecznego, jest argumentem przemawiającym za tym, że społeczeństwo w Polsce powinno coraz bardziej być zaangażowane w tego typu działania. Możliwości finansowania innowacji z funduszy unijnych oraz dobre praktyki w tym obszarze pokazują i zachęcają, aby innowacje społeczne wdrażać na poziomie lokalnym i krajowym.
SŁOWA KLUCZOWE

INNOWACJE SPOŁECZNE, SPOŁECZEŃSTWO OBYWATELSKIE, SIECI WSPÓŁPRACY, TYPY INNOWACJI SPOŁECZNYCH 


\section{Wprowadzenie}

Współczesne zmiany społeczno-gospodarcze niosą ze sobą problemy i kryzysy dotykające rozmaite kategorie i grupy społeczne, np. bezrobocie wśród ludzi młodych. Organizacje międzynarodowe, regionalne i lokalne są po to, by te problemy niwelować. Innowacje społeczne są zaś narzędziem stwarzającym możliwości organizacjom, by właśnie owe problemy łagodzić i rozwiązywać. Odróżniają się one od innych typów innowacji tym, że w ich proces angażują się zarówno twórcy, jak i odbiorcy wprowadzonych innowacji. Tym samym innowacje społeczne stają się działaniem zbiorowym, pozwalającym implementować pomysły oraz angażować różne środowiska i podmioty.

Współpraca i partnerstwo wszystkich uczestników tych działań stanowią nieodłączne elementy funkcjonowania organizacji. Obie te formy aktywności stwarzają warunki realizacji innowacji społecznych, które są wyzwaniem dla organizacji wspierających szczególnie grupy wykluczone społecznie.

Nasuwa się tu pytanie, czy zatem w realiach polskiego życia gospodarczego i prowadzonej polityki głównie według zaleceń Unii Europejskiej oraz wewnętrznych regulacji prawnych istnieją realne szanse, by takie innowacje tworzyć? Czy organizacje pozarządowe mają odpowiednie warunki na rozwój innowacji społecznych?

Artykuł jest próbą analizy socjologicznej faktycznego stanu implementacji innowacji społecznych w polskich organizacjach pozarządowych oraz możliwości ich rozwoju. Czy i w jakim stopniu owa ambitna próba będzie właściwa - autorce trudno przewidzieć i skonstatować.

\section{Pojęcie, cele i obszary innowacji społecznych}

W literaturze z zakresu nauk społecznych i ekonomicznych znajdujemy wiele definicji innowacji społecznych. Ryszard Praszkier i Andrzej Nowak (2005, s. 140) określają innowację społeczną jako:

- nowe idee, które mają racje bytu i pozwalają na osiąganie celów społecznych, które odróżniają innowacje od ulepszeń, które przejawiają się tylko stopniowo w zmianach społecznych oraz różnią się też od kreatywności i inwencji;

- tworzenie i wdrażanie nowych idei w zakresie organizowania działalności lub stosunków społecznych w celu osiągnięcia wspólnych celów.

Według TEPSIE (The Theoretical, Empirical and Policy Foundations for Building Social Innovation in Europe) poprzez innowacje społeczne rozumie się nowe rozwiązania odnoszące się do produktów, usług, modeli, rynków, procesów itp., które jednocześnie spełniają społeczną potrzebę (skuteczniej niż inne rozwiązania) i doprowadzają do nowych lub ulepszonych funkcji i relacji oraz lepszego wykorzystania zasobów i środków.

Analiza pojęcia „innowacja społeczna” z uwzględnieniem jej osobliwości i atrybutów pozwala na stwierdzenie, że jest ona znaczeniowo bliska strategicznemu rozumieniu koncepcji odpowiedzialności społecznej przedsiębiorstwa (Corporate Social Responsibility - CSR). Ta konstrukcja wynika z wielu zapisów i wzorców działań adresowanych do CSR. Jest to określane jako:

- uwzględnienie obok biznesowych, społecznych, etycznych i ekologicznych aspektów w działalności przedsiębiorstwa; 
- osiąganie zysku przy jednoczesnym mądrym kształtowaniu relacji z odbiorcami oraz dostarczenie na rynek wyrobów i usług z poszanowaniem środowiska naturalnego i społecznego;

- opracowanie strategii opartych na zaangażowaniu społecznym, wykraczającym poza minimalne zobowiązania prawne i mającym na celu dobro wszystkich obywateli, zgodnie z normami etycznymi;

- współpraca z pracownikami, społecznościami lokalnymi, regionalnymi i globalnymi mająca na celu podnoszenie jakości życia wszystkich obywateli;

- przyjęcie odpowiedzialności za otoczenie, w którym działa przedsiębiorstwo;

- dbanie o wszechstronny rozwój pracowników (Brdulak, 2011, s. 248).

Przejawem tych założeń mogą być najprostsze innowacje wprowadzane w przedsiębiorstwach, np. finansowanie zakupu komputerów, ale także inicjatywy daleko wykraczające poza prostą charytatywność, a skierowane ku prowadzeniu tzw. zrównoważonego biznesu, tj. zgodnego z ekologią i ochroną środowiska, dbającego o zadowolenie pracownika, czy wprowadzające wartości dodane dla rozwoju firmy w kontekście fair trade (Marciniec, 2009).

Innowacje społeczne pojawiają się w kontekście pięciu następujących obszarów kreowania społeczeństwa obywatelskiego. Pierwszy z nich dotyczy transformacji społecznej. Przejawia się on w formie społeczeństwa obywatelskiego, w procesie przemian społecznych oraz wzrostu roli ekonomii społecznej. Ważnym czynnikiem tego obszaru innowacji jest udział biznesu w zmianie społecznej (społeczna odpowiedzialność biznesu) i przedsiębiorstw w prowadzeniu kolejnej fali innowacji i produktywności poprzez skupienie się na „społecznych” dziedzinach zwłaszcza takich, jak edukacja czy opieka zdrowotna. Drugi obszar to model zarządzania organizacją uwzględniający budowanie strategii biznesowych obejmujących zmiany w kapitale ludzkim, instytucjonalnym i społecznym, które prowadzą do poprawy sprawności organizacyjnej i poprawy konkurencyjności oraz poprawy zarządzania zasobami ludzkimi. Trzeci obszar innowacji społecznych to przedsiębiorczość społeczna, czyli rozwój nowych i innowacyjnych sposobów pokonywania trudnych wyzwań społecznych poprzez zaangażowanie przedsiębiorców „wrażliwych społecznie”. Przedsiębiorstwa społeczne to przede wszystkim przedsiębiorstwa z celami społecznymi, których nadwyżki są aplikowane na ich rozwój. Czwarty obszar to rozwój nowych produktów, usług i programów zaspokajających potrzeby społeczne, innowacyjne w sektorze publicznym i świadczenia usług publicznych przez przedsiębiorstwa społeczne i organizacje społeczeństwa obywatelskiego; świadczenie usług publicznych i innych środków redystrybucji w kierunku oszczędności budżetowych w państwie dobrobytu. Piąty obszar innowacji społecznych to model zarządzania, wzmocnienie pozycji i zwiększenia zdolności instytucji społecznych, w tym poprawa wzajemnych relacji między różnymi podmiotami społecznymi, poprawa umiejętności, kompetencji i kapitału społecznego wśród aktorów życia społecznego zaangażowanych w rozwój i realizację programów oraz strategii społecznych i gospodarczych (Wronka-Pośpiech, 2015, s. 126). 
Podsumowanie pięciu szerokich zastosowań pojęcia innowacji społecznych

\begin{tabular}{|l|l|}
\hline \multicolumn{1}{|c|}{ Obszar innowacji społecznych } & \\
\hline \multirow{3}{*}{$\begin{array}{l}\text { Proces zmian społecznych } \\
\text { i transformacji społecznych }\end{array}$} & Rola społeczeństwa obywatelskiego w zmianie społecznej \\
\cline { 2 - 3 } & Rola ekonomii społecznej i przedsiębiorstw społecznych \\
\cline { 2 - 2 } & Rola biznesu w zmianie społecznej \\
\hline \multirow{5}{*}{ Strategie biznesowe i organizacyjne } & Kapitał społeczny i instytucjonalny \\
\cline { 2 - 2 } & Sprawność organizacyjna, przywództwo i konkurencyjność \\
\cline { 2 - 2 } & Trwałość i skuteczność organizacji non profit \\
\cline { 2 - 2 } & Rola jednostki w tworzeniu przedsięwzięć społecznych \\
\cline { 2 - 2 } & Zachowania i postawy związane z przedsiębiorczością społeczną \\
\cline { 2 - 2 } & Firmy koncentrujące się na celach społecznych \\
\hline \multirow{3}{*}{ Nowe produkty, usługi i programy } & Innowacyjność sektora publicznego \\
\cline { 2 - 2 } & $\begin{array}{l}\text { Świadczenia usług publicznych przez przedsiębiorstwa społeczne i organizacje } \\
\text { społeczeństwa obywatelskiego }\end{array}$ \\
\hline Budowanie kapitału ludzkiego & Wzajemne powiązanie między różnymi podmiotami, umiejętności, kompetencje \\
\hline Polityka & Opracowanie programów i strategii \\
\hline
\end{tabular}

Źródło: TEPSIE (2012).

Istotnymi atrybutami innowacji społecznych są takie jej cechy, jak:

- międzysektorowość, bo innowacje społeczne często przemieszczają się między sektorami. Innowacje społeczne występują na granicy między różnymi sektorami i angażują we wspólnym działaniu ludzi pracujących w różnych sektorach;

- otwartość i współpraca, ponieważ innowacje społeczne często włączają i angażują dużą liczbę ludzi i organizacji społecznych;

- działania oddolne to innowacje społeczne mające często charakter inicjatyw oddolnych i lokalnych;

- prosumpcja i koprodukcja, coraz częściej granica między producentem i konsumentem się zaciera;

- mutualizm, czyli przekonanie, że indywidualne i zbiorowe samopoczucie można uzyskać jedynie na drodze wzajemnej pomocy, co możliwe jest dzięki np. nowych technologiom;

- tworzenie nowych ról i relacji społecznych - innowacje społeczne są związane i rozwijane przez użytkowników, a nie dostarczane do i dla nich. Społeczne innowacje mogą być zatem określone na podstawie rodzaju związków, które tworzą. Innowacje społeczne mogą stworzyć nowe stosunki społeczne. W różnoraki sposób mogą prowadzić do nowych form zarządzania, nowych i lepszych form wspólnego działania, poprawy integracji i uczestnictwa grup marginalizowanych, niedostatecznie reprezentowanych. Innowacje społeczne tworzą również nowe role dla użytkowników i beneficjentów, wzmacniając ich pozycje w społeczeństwie;

- lepsze wykorzystanie środków i zasobów - innowacje społeczne często pozwalają na lepsze wykorzystanie zasobów i aktywów, które w wielu sytuacjach mogłyby być zmarnowane lub niewykorzystane;

- rozwijanie zasobów i możliwości. Wiele innowacji społecznych wyraźnie ma na celu rozwijanie możliwości beneficjentów, umożliwiających zaspokojenie ich potrzeb w dłuższym okresie (Kwaśnicki, 2015, s. 19-20).

W analizie TEPSIE dodano jeszcze takie trendy, jak: 
- projektowanie, które odegrało znaczącą rolę w tworzeniu innowacji społecznych;

- myślenie systemowe, ponieważ kluczowe problemy społeczne są złożone i wymagają długotrwałego zaangażowania wielu podmiotów (Knop, Szczepaniak, Olko, 2014, s. 243).

Cele innowacji społecznych to przede wszystkim odpowiedź na problemy społeczne w różnych aspektach. Według Komisji Europejskiej innowacje społeczne to innowacje, które są zarówno społeczne w celach, jak i w środkach, pozostając otwarte na zróżnicowanie terytorialne, kulturowe itp. Społeczne w sensie zarówno procesu, jak i celów społecznych, które każdy chciałby osiągnąć. Opierają się one na pomysłowości obywateli, organizacjach społeczeństwa obywatelskiego, społecznościach lokalnych, przedsiębiorcach i urzędnikach państwowych, „a ich podstawowym zadaniem jest stwarzanie okazji zarówno dla sektora publicznego, jak i dla rynków, dzięki czemu produkty i usługi będą spełniać lepiej indywidualne, ale również i zbiorowe aspiracje" (European Commision, 2013). Komisja Europejska uznała, że innowacje społeczne mogą być wykorzystywane w takich kwestiach, jak:

- sprawne i skuteczne rozwiązywanie problemów społecznych;

- wsparcie w zakresie kształcenia ustawicznego w celu zapewnienia odpowiednich warunków życia;

- pozyskiwanie środków prywatnych i pozarządowych w celu uzupełnienia finansowania z budżetu państwa;

- wspomaganie państw w podejmowaniu reform i innych decyzji politycznych w na podstawie wiedzy;

- współtworzenie strategicznych inwestycji społecznych (European Commision, 2013).

Według Organization for Economic Co-operation and Development innowacje społeczne „nie odnoszą się do wprowadzenia nowych rodzajów produkcji lub wykorzystywania nowych rynków ze względu na ich wykorzystanie dla zysku, ale ich głównym celem jest zaspokojenie nowych potrzeb, niedostarczanych przez rynek lub tworzenie nowych, bardziej satysfakcjonujących sposobów aktywizacji, dając ludziom miejsca pracy i zmieniając ich role w procesie produkcji” (OECD, 2011).

Innowacje społeczne szukają nowych odpowiedzi na problemy społeczne poprzez: identyfikację oraz dostarczenie nowych usług, które poprawiają jakość życia osób, wspólnot, i pozwalają na opracowanie, a także wdrożenie nowych procesów integracji na rynku pracy, nowych umiejętności, nowych miejsc pracy, nowych form uczestnictwa jako różnorodnych elementów, które przyczyniają się do poprawy sytuacji osób na rynku pracy (Kwaśnicki, 2015, s. 14).

Jak pisze Martyna Wronka-Pośpiech (2015), innowacje społeczne wykraczają poza sektor gospodarczy i mogą odnosić się zarówno do szeroko pojętego państwa, jak i społeczeństwa obywatelskiego wyrażonego przez tzw. trzeci sektor. Oznacza to, że innowacje społeczne nie powstają w jednym miejscu i mogą stanowić wypadkową rezultatów działania kilku organizacji czy osób z różnych sektorów (s. 128). Inne cechy systemu innowacji społecznych, na które zwraca się uwagę, to: otwarty, a nie zamknięty ich charakter (jeśli chodzi o dzielenie się wiedzą); wielodyscyplinarność i bardziej zintegrowany niż „tradycyjne innowacje"; partycypacyjny, z dużym udziałem obywateli i użytkowników; napędzany przez popyt, nie przez podaż; skrojony na indywidualne potrzeby, a nie skupiony na masowej produkcji (Kwaśnicki, 2015, s. 14).

Nie można mówić o innowacjach społecznych bez uwzględniania przedsiębiorczości społecznej. Innowacja społeczna jest warunkiem koniecznym zaistnienia przedsiębiorczości społecznej w sferze gospodarczej. Jest to umiejętność znalezienia nowego sposobu 
działania w określonych sytuacjach i stanowi nieodłączną część definicji przedsiębiorcy społecznego obok innowacji społecznej, inne cechy to: misja społeczna, zmiana społeczna, duch przedsiębiorczości, osobowość rozumiana jako kreatywność i przedsiębiorczość (Kroik, Skonieczny, 2013, s. 165). Innowacje społeczne pomagają w identyfikowaniu i promowaniu nowych podejść do problemów społecznych.

W Polsce przedsiębiorczość społeczna wspierana przez organizacje pozarządowe zaczyna stanowić ważny element społeczeństwa obywatelskiego. Inicjatywy podejmowane przez przedsiębiorstwa społeczne, szczególnie w środowiskach lokalnych, stanowią silne wsparcie i odpowiedź na konkretne potrzeby lokalne. Przedsiębiorca społeczny motywuje do działania pozostałą społeczność. Wyznacza nowe szlaki, dysponując nowatorskimi ideami, łączy wizję z realizmem, cechuje się kreatywnością w rozwiązywaniu problemów, jest bardzo etyczny i całkowicie pochłonięty swoją wizją zmiany (Bornstein, 2004). Przedsiębiorca społeczny odgrywa ważną rolę, ponieważ jest inicjatorem projektów społecznych.

W literaturze przedmiotu znajduje się wiele definicji innowacji społecznych. Ich autorzy, zwracają uwage na ich charakterystyczne atrybuty. Można skonkludować, że najważniejszą z nich jest prospołeczny charakter, gdyż ich twórcy nie kierują się tylko komercyjnym zyskiem. W artykule zostały zaznaczone jedynie podstawowe i możliwe obszary ich realizacji, ponieważ wykraczają one poza sztywne ramy danej klasyfikacji. W szybko zmieniającym się społeczeństwie proces tworzenia innowacji społecznych i obszary ich zastosowań jest ciągle dynamiczny.

\section{Proces tworzenia innowacji społecznych oraz ich funkcje i znaczenie}

Dla lepszego zrozumienia istoty innowacji społecznych należy przedstawić ich proces tworzenia. W rozumieniu UE innowacje społeczne odnoszą się do całego procesu, w którym odpowiedzi na potrzeby społeczne zostały wypracowane celem dostarczenia lepszych rezultatów społecznych. Proces ten składa się z czterech głównych elementów a mianowicie:

- identyfikacji nowych, niezaspokojonych lub niedostatecznie spełnionych potrzeb społecznych;

- rozwoju nowych rozwiązań w odpowiedzi na te potrzeby;

- oceny skuteczności nowych rozwiązań w zaspokojeniu potrzeb społecznych;

- skalowania skutecznych innowacji społecznych (European Commision, 2013).

Z kolei. Murray, Caulier-Grice oraz Mulgan (2010) ujmują proces tworzenia innowacji w sześciu etapach:

1) symptomów potrzeby zmiany;

2) generowania pomysłów odpowiadających identyfikowanej potrzebie zmiany;

3) tworzenia i testowania prototypów rozwiązań;

4) upowszechniania nowego rozwiązania;

5) zmian systemowych uwarunkowanych często zaangażowanych wszystkich sektorów;

6) interakcji różnych elementów wprowadzenia zmiany, m.in. nowych regulacji prawnych, zmian w sposobie myślenia, nowego modelu, ruchu społecznego na rzecz zmian.

Innowacje społeczne zawierają pięć elementów, które tworzą strukturę. Są nimi nowość, droga „od pomysłu do realizacji”, skuteczność, spełnianie potrzeby społecznej, poprawa zdolności społeczeństwa do działania (Kwaśnicki, 2015, s. 18).

Innowacje społeczne angażują aktywne społeczeństwo w kształtowaniu zmian społecznych. Zmiana społeczna według Piotra Sztompki „to różnica między stanem systemu społecznego (grupy, organizacji) w jednym momencie czasu i stanem tego samego systemu 
w innym momencie czasu” (2002, s. 437). Natomiast zdaniem Anthony'ego Giddensa, zmiana społeczna w epoce nowoczesnej zachodzi szczególnie szybko (2004, s. 739). „Innowacje społeczne są to elementy zmiany społecznej, jednocześnie tworzące zmiany społeczne (Howaldt, Schwarz, 2010, s. 28). Według Anny Olejniczuk-Merty „są one postrzegane jako zmiany procesowe, w których kreowaniu, wdrażaniu i upowszechnianiu uczestniczą różne grupy społeczne, a zwłaszcza zaś zawodowe, a nawet znaczna część społeczeństwa" (2013, s. 27). W tym aspekcie należy uwzględnić takie czynniki, jak charakter zmian, ich zakres, czas powstania, efekt zmian. „Innowacje społeczne mogą być zatem nieprzewidywalne, dzieje się tak, gdy mamy do czynienia z jednorazową małą zmianą lub wtedy, gdy w wyniku innowacji zamierzonych otrzymujemy efekt «ekstra» o istotnym znaczeniu społecznym” (s. 27). „Dla trwałości zmiany społecznej kluczowe wydaje się jej takie wprowadzenie, które wpisuje się w mechanizmy regulacyjne systemu" (Praszkier, Nowak, 2005, s. 5).

Innowacje społeczne muszą być nowe w pewnym zakresie, tak by móc je zakwalifikować jako innowacje społeczne. Muszą spełnić zatem cechy nowości w jakiejś dziedzinie, branży, regionu lub użytkownika, albo są stosowane w nowy sposób (Kwaśnicki 2015). Innowacja pociąga za sobą praktyczne zastosowanie lub realizację nowego pomysłu idei. Niektóre wynalazki, jak stwierdza Kwaśnicki (2015), prowadzą do innowacji, ale najczęściej tak nie jest. Bywają często szeroko rozpowszechnione, a w niektórych przypadkach trudno jest odróżnić wynalazek od innowacji. „W przypadku wielu innowacji istnieje znaczne opóźnienie między momentem dokonania wynalazku i innowacji” (s. 18). Skuteczność to kolejna cecha innowacji społecznych. Według tego autora „skuteczność może dotyczyć jakości, poziomu satysfakcji z obsługi, szybkości rozprzestrzeniania się (dyfuzji), zmniejszenia kosztów lub wpływu na wzrost zadowolenia społecznego, jak np. poprawa samopoczucia i większa spójność społeczna" (s. 18). Ta ocena może przyjmować postać mierzalnych rezultatów w wymiarze ilościowym i jakościowym. Oceny skuteczności mogą być związane z systemem wartości społecznych, które innowacja ma poprawić, np. zmniejszenie izolacji osób starszych jest oceniane jako pożądany wynik na podstawie wartości społecznych, które podkreślają znaczenie godności i dobrego samopoczucia. „Kolejną cechą wyróżniającą innowację społeczną jest to, że została wprowadzona w celu spełnienia potrzeby społecznej" (Kwaśnicki, 2015, s. 18). Potrzeby społeczne są przydatniejszą perspektywą w określaniu innowacji społecznych aniżeli analiza społeczna przez pryzmat problemów, jak np. ubóstwo czy nierówności. To dlatego, że potrzeby społeczne w przeciwieństwie do problemów społecznych nie stygmatyzują grupy społecznej np. bezrobotnych. Zrozumienie istnienia i dynamiki niespełnienia potrzeb może pomóc w określeniu identyfikacji pożądanej strategii i zaangażowania ludzi do poszukiwania nowych i lepszych sposobów, tak aby spełnić te potrzeby (Kwaśnicki, 2015, s. 18).

Ostatnim elementem innowacji społecznych jest poprawa zdolności społeczeństwa do działania. Proces innowacji społecznych powinien zwiększać zdolność społeczeństwa do działania m.in. poprzez tworzenie nowych ról i relacji, rozwój dostępnych zasobów i możliwości wykorzystania zasobów i środków. Proces innowacji społecznych często pociąga za sobą zmiany w relacjach społecznych, w szczególności w zakresie zarządzania i zwiększenia udziału grup społecznych narażonych na marginalizację. W tym sensie innowacje społeczne wymagają zmian w relacjach władzy i zwiększenia potencjału społeczno-politycznego oraz zwiększenia dostępu do zasobów przez beneficjentów. Jest to jeden z najbardziej niedostatecznie zbadanych i wymagających wyjaśnienia elementów innowacji społecznych 
(Kwaśnicki, 2015, s. 18). Innowacje społeczne mogą stworzyć nowe stosunki społeczne w różnoraki sposób - mogą prowadzić do nowych form zarządzania, nowych i lepszych form wspólnego działania, poprawy integracji i uczestnictwa grup marginalizowanych. Mogą one przesuwać i zmieniać relacje w całości, np. poprzez umożliwienie użytkownikom stać się producentami, pacjentom stać się opiekunami, studentom być nauczycielami (Kwaśnicki, 2015, s. 18-19).

W Polsce brakuje systemowego podejścia do zarządzania wiedzą o innowacjach społecznych, co skutkuje marnowaniem potencjału wykorzystywanego w ramach projektów finansowanych z Unii Europejskiej. Odpowiedzią na ten problem mogłoby być stworzenie systemu dyfuzji innowacji społecznych. Funkcją systemu byłoby ułatwienie dostępu do szczegółowej wiedzy na temat najlepszych praktyk dotyczących innowacji społecznych (Sempruch, 2012, s. 44).

Warto zapytać, jakie innowacje społeczne są w Polsce najbardziej potrzebne? Agnieszka Skowrońska (2016, s. 1) wymienia następujące obszary, które wymagają zmian:

- profilaktyka społeczna skierowana szczególnie do dzieci i młodzieży, obejmująca wszelkie-

go typu nowe sposoby przekazywania prawidłowych postaw prozdrowotnych, np. w zakresie odżywiania, zachowań w sytuacjach trudnych, np. agresja ze strony dorosłych i rówieśników, przeciwdziałania uzależnieniom;

- działalność zawodowa, która powinna być źródłem samorealizacji, a nie tylko sposobem na zarobienie pieniędzy;

- role społeczne osób niesamodzielnych życiowo, ale będących w wieku produkcyjnym. Innowacje w tym zakresie powinny dążyć do poszukiwania ról, które są ważne dla funkcjonowania całego społeczeństwa, aby te osoby mogły czuć się jego częścią;

- radzenie ze społecznymi skutkami starzenia się, które są spowodowane szybkim rozwojem medycyny.

Autorka stwierdza, że wydłużająca się średnia długość życia nie idzie w parze z zadowoleniem osób starszych z tego przedłużonego życia. Nowe sposoby na poradzenie sobie z tymi problemami będą obejmować różnorodne formy opieki, a także znajdowania możliwości funkcjonowania w społeczeństwie (Skowrońska, 2016, s. 1).

Innowacje społeczne są odpowiedzią na potrzeby społeczne. Nowość danej innowacji nie jest wystarczająca, ponieważ o jej istocie decyduje skuteczność i zaangażowanie w ich tworzenie i realizację różnych grupy społecznych. Innowacje społeczne nie są zamknięte w laboratoriach i wąskim gronie ich twórców, ale wpisane w codzienną aktywność społeczną obywateli. Innowacje te dają możliwość nawet osobom i grupom wykluczonym społecznie, by być aktywnym i twórczym podmiotem życia społecznego.

\section{Rola sieci współpracy oraz typy innowacji społecznych}

Teorie innowacji coraz częściej wskazują na fakt, że powiązania sieciowe nie tylko są źródłem poszerzania wiedzy, lecz także pozwalają organizacjom na tworzenie wspólnych przedsięwzięć. Z jednej strony mowa w nich o organizacjach korzystających z różnorakich powiązań sieciowych (w tym kooperantów), z drugiej o lokalnych bądź regionalnych systemach sieciowych tworzonych oddolnie przez ośrodki innowacji i przedsiębiorstwa, a wspieranych przez instytucje publiczne oraz charakteryzujących się dużą elastycznością i adaptacyjnością (Szczepaniak, 2014, s. 161). 
Celem budowania sieci jest tworzenie nowych rozwiązań oraz dzielenie się wiedzą i doświadczeniem. W procesie budowania sieci na rzecz tworzenia innowacji społecznych najważniejszym z czynników jest kapitał ludzki.

Zarządzanie zasobami ludzkimi staje się bliskie tworzeniu biznesu opartego na sieciach, pojedynczych inwestycjach w pojedyncze postacie, produktach wirtualnych. Na czoło priorytetów wysuwa się równowaga między elastycznością i trwałością oraz przetrwanie dzięki aliansom postaci, sieciom wsparcia społecznego, nieszablonowym inwestycjom w osoby. Wyłania się problem także ryzyka biznesowego, opcji, które zaczynają wyraźnie towarzyszyć działaniom i decyzjom specjalistów z zakresu zarządzania (Strużyna, 2010, s. 20).

Analizując rolę czynnika ludzkiego w przedsiębiorstwach stosujących nowoczesne metody zarządzania, najłatwiej można zaobserwować proces przechodzenia od zarządzania zasobami ludzkimi do zarządzania kapitałem ludzkim, w największym stopniu biorącym udział w tworzeniu wartości dodanej organizacji. Kapitał ludzki może być analizowany na wielu różnych poziomach odniesienia: makro, mezzo i mikro, czyli z kapitałem ludzkim mamy do czynienia nie tylko w organizacjach, lecz także w szerszych grupach społecznych, wychodzących poza ramy organizacji. W szczególności podkreśla się, że kapitał ludzki wywiera poważny wpływ na innowacyjność gospodarek kraju i społeczeństw, ich zdolności absorpcyjne w zakresie przyswajania i wdrażania światowych osiągnięć naukowych, technicznych, organizacyjnych, mentalnościowych itp. Wywiera on wpływ na przemiany instytucjonalne i unowocześnienie struktur różnego rodzaju. Kapitał ludzki sprzyja propagowaniu i upowszechnianiu nowoczesnych wzorców konsumpcji i jakości życia oraz kształtuje nowoczesną infrastrukturę techniczno-organizacyjną, informatyczną, socjalną (Harasim, 2013, s. 31).

Proces budowy sieci współpracy wymaga zaangażowania trzech środowisk: biznesu, nauki i administracji. Innowacje społeczne często przemieszczają się między sektorami, np. wiele modeli kształcenia na odległość zostało zainicjowanych przez organizacje non profit, a następnie przyjętych przez przedsiębiorstwa handlowe lub społeczne, często innowacje społeczne występują na granicy między różnymi sektorami (Kwaśnicki, 2015, s. 18). W przypadku tworzenia innowacji społecznych często mamy do czynienia z ideą poczwórnej helisy, gdzie obok wspomnianych trzech sektorów sytuuje się społeczeństwo obywatelskie. Model w zależności od usytuowania poszczególnych elementów, rodzaju innowacji, inicjatorów procesów innowacyjnych i odbiorców ich efektów może występować w różnych wariacjach (Szczepaniak, 2014, s. 161).

Egzemplifikacją tego może być poczwórna helisa, która nie jest statycznym modelem, lecz raczej pewnym kontinuum, ciągiem współzależnych zdarzeń. Autorzy Exploring the Quadruple Helix Report of Quadruple Helix wyróżnili cztery typy poczwórnej helisy: model potrójnej helisy wraz z użytkownikami, model z centralnie usytuowanym sektorem biznesu, model z centralnie usytuowanym sektorem publicznym oraz model, w którym społeczeństwo obywatelskie stanowi centrum. Każdy z typów poczwórnej helisy ma właściwe dla siebie cele i rodzaje przeważających innowacji, sposoby pełnienia ról inicjatorów procesów innowacyjnych, a także relacji z interesariuszami (Szczepaniak, 2014, s. 161-162). Najważniejszym typem poczwórnej helisy mającej największe znaczenie dla rozwoju innowacji społecznych jest rozwiązanie, w którym w centrum są ludzie. To aktywni aktorzy życia społecznego decydują, które z innowacji są potrzebne i będą rozwijane, zaś pozostałe sektory wspierają ich w aktywności innowacyjnej (s. 161). 
Poszczególni autorzy rozwijający koncepcję krajowego systemu innowacji akcentują inne jego elementy i wydzielają różne części składowe. Według Lundvalla narodowy system innowacji składa się z trzech podsystemów: produkcji, marketingu i finansów, natomiast Patel i Pavitt wyróżniają cztery zasadnicze elementy tego systemu: firmy, instytucje badawcze, instytucje edukacyjne i rząd (za: Olechnicka, Płoszaj, 2010). Najczęściej charakteryzuje się go jako układ trzech typów organizacji - edukacyjnych, badawczych i przedsiębiorstw funkcjonujących w szczególnym otoczeniu instytucjonalnym. Podkreśla się przede wszystkim, że narodowe gospodarki są zróżnicowane pod względem struktury systemów produkcyjnych i konstrukcji instytucjonalnych, a istoty systemu innowacji upatruje się w kształcie sieci współdziałających instytucji (Okoń-Horodyńska, 1998).

W ostatnich latach wyłania się nowy mutualizm wymiany w obrębie powstających sieci. Przykładem są sieci typu peer to peer, takie jak Etsy - sieci mikroprzedsiębiorców, FreeCycle i nowe modele opieki oraz wsparcia, takie jak Southwark Circle czy Homeshare. Taka współpraca w sieciach pozwala na tworzenie nowych ról i relacji społecznych. Innowacje społeczne mogą stworzyć nowe stosunki społeczne w różnoraki sposób - mogą prowadzić do nowych form zarządzania, nowych i lepszych form wspólnego działania, poprawy integracji i uczestnictwa grup marginalizowanych, np. program Expert Patients (Szczepaniak, 2014, s. 164).

„Najogólniejsze i zarazem najbardziej rozpowszechnione ujęcie akcentujące znaczenie współpracy dla innowacyjności w wymiarze przestrzennym to koncepcja krajowego systemu innowacji oraz bezpośrednio z nią związana koncepcja regionalnego systemu innowacji” (Olechnicka, Płoszaj, 2010, s. 202). Początki myślenia w kategoriach krajowego systemu innowacji wiążą się z zakwestionowaniem liniowego modelu procesu innowacyjnego i zastąpieniem go podejściem wskazującym bardziej na skomplikowanie tego procesu oraz na efekty mnożnikowe występujące w wyniku interakcji pomiędzy systemami technologicznymi, ekonomicznymi, społecznymi i zarządczymi (Okoń-Horodyńska, 1998).

W innowacjach społecznych należy również wziąć pod uwagę czynnik ekonomiczny i biznesowy. Jest to związane np. z partnerstwem biznesowym w sieciach i klastrach innowacji społecznych, a także wytworzeniem zysków ekonomicznych. Rosabeth M. Kanter pisze, że „istotą przedsiębiorstwa jest przesłanie społeczne (misja), dobór partnerów biznesowych i społecznych, zaangażowanie w tworzenie nowych wartości, jakość innowacji, siła powiązań z innymi podmiotami na rynku” (2006, s. 170). Jednym z podejść innowacji społecznych związanych z biznesem jest koncepcja (Creating Shared Value) znana jako kreowanie wartości ekonomiczno-społecznej. Podstawą tej koncepcji jest określenie dokładnych punktów przecięcia interesów firmy i społeczeństwa, czyli inicjatyw i działań tworzących przewagę konkurencyjną przedsiębiorstwa, a jednocześnie przynoszących korzyści społeczne. Innowacyjność jest tu „paliwem” takiej aktywności i w sposób naturalny wchłania innowację społeczną do modelu biznesowego firmy. Do nurtu wiązania wartości społecznych i ekonomicznych można zaliczyć pojęcie tzw. hybrydowego łańcucha wartości (Hybryd Chain Value - HCV), tym samym innowacją społeczną stają się nie tylko spektakularne pomysły, jak np. udzielanie kredytów, lecz także wszelkie zmiany przyjmowane przez grupy społeczne jako nowy i/lub udoskonalony sposób zaspokajania zgłaszanych potrzeb społecznych (Kroik, Malara, 2013, s. 356).

We współczesnym rozwoju ICT ważnym rodzajem innowacji społecznych są te technologiczne innowacje społeczne, w których skład można zaliczyć wszelkie społeczne rozwiązania innowacyjne oparte na wykorzystaniu nowoczesnych technologii: komputery, 
technologie informacyjne, informatyczne i telekomunikacyjne. Wśród tych innowacji społecznych należy wymienić nauczanie przez Internet takie jak e-learning, dostęp do bibliotek internetowych, wykłady i szkolenia online (Marciniec, 2009).

Innowacje społeczne nie są możliwe bez wdrażania odpowiednich narzędzi prawnych i prowadzenia polityk sprzyjających ich rozwojowi w wymiarze polityki Unii Europejskiej, polityki państwa oraz polityki lokalnej na poziomie regionów, powiatów i gmin. Innowacje społeczne zostały włączone do polityki Unii Europejskiej. Mają być środkiem do realizacji celów strategii „Europa 2020”, są zawarte w takich dokumentach, jak Unia Innowacji (2014), Inicjatywa na rzecz przedsiębiorczości społecznej (2011), Krajowy Program Przeciwdziałania Ubóstwu i Wykluczeniu Społecznemu 2020 (2014), Europejskie partnerstwo na rzecz innowacji sprzyjającej aktywnemu starzeniu się w dobrym zdrowiu (2012), Europejska Agenda Cyfrowa (2014) i inne. W dokumencie Guide to Social Innovation (2013) Komisja Europejska określiła sześć obszarów życia społecznego, w których innowacje społeczne mogą odegrać szczególną rolę. Są nimi: migracje i proces starzenia się społeczeństwa, ochrona środowiska i zmiany klimatyczne, społeczeństwo informacyjne, ubóstwo i wykluczenie społeczne, zdrowie, uczciwa konkurencja (Guide to Social Innovation, 2013).

W perspektywie finansowej 2014-2020 innowacje społeczne znalazły się w rozporządzeniach dotyczących funduszy strukturalnych zarówno Europejskiego Funduszu Społecznego, jak i Europejskiego Funduszu Rozwoju Regionalnego. Programy wspierające innowacje społeczne to m.in. Program na rzecz Zatrudnienia i Innowacji Społecznych łączaccy trzy dotychczasowe programy: Progress, EURES i Europejski Mechanizm Mikrofinansowy Progress (Kamocka, 2016). Polityka społeczna może być wspierana przez działania innowacyjne w celu wsparcia obywateli (European Commision, 2015, s. 3). Wszystkie te dokumenty potwierdzają, jak istotna jest rola innowacji społecznych. Ważne jest, aby nie zostały one wpisane tylko teoretycznie w dokumentach, ale znalazły zastosowanie w praktyce.

\section{Podsumowanie}

Innowacje społeczne od zawsze towarzyszyły ludziom, a zatem nie są zjawiskiem nowym. W obliczu potrzeb ludzie szukają nowych rozwiązań, które mogą służyć poprawie życia. Dlaczego w ostatnich latach zaczęto szczególnie zwracać uwagę na innowacje społeczne? Jednym z powodów jest zwiększająca się odpowiedzialność społeczna ludzi, którzy w coraz bardziej aktywny sposób wykorzystują i sami inicjują innowacje społeczne. Możemy wymienić ich kilka poziomów, które współcześnie są wykorzystywane i promowane, np. innowacje społeczne, technologiczne i biznesowe, chociażby wykorzystywane nowe technologie czy biznesowe inicjatywy lokalne. Innowacje społeczne są najbliższe ludziom, ponieważ społeczeństwo korzysta z nich i je tworzy, nawet nie w pełni będąc tego świadome. Innowacje te są w celach i środkach skierowane dla ludzi i przez nich aktywowane. Obejmują one różne poziomy życia społecznego zarówno w skali lokalnej, jak i globalnej. Twórcami innowacji społecznych są indywidualne podmioty, grupy, a nawet tłumy.

W sytuacji kryzysu gospodarczego kraju oraz problemów społecznych (np. zwiększonej liczby migracji zarobkowych, deficytu opieki nad osobami starszymi, niedożywienia dzieci) innowacje społeczne dają możliwość tworzenia wówczas przedsięwzięć i projektów, które odpowiadają na newralgiczne problemy określonego społeczeństwa. Wymaga to jednak postawy otwartości i odpowiedzialności oraz bycia aktywnym aktorem życia społecznego. Innowacje społeczne przeczą biernej postawie, np. „inni to zrobią za mnie” lub „to mnie nie dotyczy”. Najważniejszymi atrybutami tej kategorii innowacji są konsekwentna aktywność 
społeczna i oddolne inicjatywy możliwie jak największej części mieszkańców danego kraju czy określonego regionu.

\section{LITERATURA}

Bąkowski, A., Mażewska, M. (2015). Ośrodki innowacji i przedsiębiorczości w Polsce. Warszawa: Polska Agencja Rozwoju Przedsiębiorczości.

Bornstein, D. (2004). How to Change the World. Socila Entrepreneurs and Power of New Ideas. New York: Oxford Univerfsity Press.

Giddens, A. (2004). Socjologia. Warszawa: Wydawnictwo Naukowe PWN.

Harasim, W. (2013). Zarządzanie zasobami ludzkimi i kapitałem ludszkim. W: W. Harasim (red.), Człowiek i organizacja XXI wieku (s. 8-42). Warszawa: Wyższa Szkoła Promocji.

Howaldt, J., Schwarz M. (2010). Social innovation: concepts, research fields and international trends. Pobrano z: http://www.asprea.org/imagenes/IMO\%20Trendstudie_Howaldt_englisch_Final\%20ds.pdf.

Kamocka, I. (2016). Innowacje społeczne w rozwiązywaniu problemów miast. Pobrano z: http:// www.schuman.pl/pl/materialy/3339-innowacje-spoleczne-w-rozwiazywaniu-problemow-w-miastach.

Kanter, R.M. (2006). Innovation: the classic traps. Harvard Business Review, 84 (11), 72-83.

Knop, L., Szczepaniak, M., Olko, S. (2014). Innowacje społeczne w kreatywnej Europie w perspektywie strategii Europa 2020. Organizacja i Zarządzanie, 73, 239-253.

Kroik, J., Malara, Z. (2013). Innowacje społeczne jako przesłanka modelu biznesowego. Zeszyty Naukowe Ostrołeckiego Towarzystwa Naukowego, 27, 354-368.

Kroik, J., Skonieczny, J. (2013). Innowacja społeczna a społeczna odpowiedzialność przedsiębiorstwa. Pobrano z: http://ptzp.org.pl/files/konferencje/kzz/artyk_pdf_2013/p014.pdf.

Kwaśnicki, W. (2015). Innowacje społeczne - nowy paradygmat czy kolejny etap w rozwoju kreatywności człowieka? W: W. Misztal, G. Chimiak, A. Kościański, Obywatelskość wobec kryzysu: uśpieni czy innowatorzy? (s. 1-23). Warszawa: Instytut Filozofii i Socjologii PAN.

Marciniec, B. (2009). Czym są innowacje społeczne. Innowacyjny Start, 2 (12), DOI: http://www. pi.gov.pl/Firma/chapter_95852.asp.

Murray, R., Caulier-Grice, J., Mulgan, G. (2010). The Open Book of Social Innovation. The Young Foundation: NESTA.

Okoń-Horodyńska, E. (1998). Narodowy system innowacji w Polsce. Katowice: Wydawnictwo Uczelniane Akademii Ekonomicznej w Katowicach.

Olechnicka, A., Płoszaj, A. (2010). Sieci współpracy receptą na innowacyjność regionu? W: Europejskie wyzwania dla Polski i jej regionów. Warszawa: Ministerstwo Rozwoju Regionalnego.

Olejniczuk-Merta, A. (2013). Innowacje społeczne. Konsumpcja i Rozwój, 4, 21-34.

Praszkier, R., Nowak, A., (2005). Zmiany społeczne powstałe pod wpływem działalności przedsiębiorców społecznych. Trzeci Sektor, 2, 140-157.

Sempruch, G. (2012). Innowacje społeczne - innowacyjne instrumenty polityki społecznej w projektach finansowanych ze środków Europejskiego Funduszu Społecznego. Zarządzanie Publiczne, 2 (18), 33-45. 
Skowrońska, A. (2016). Jakie innowacje społeczne są w Polsce najbardziej potrzebne? Pobrano z: http://innpoland.pl/124687,jakie-innowacje-spoleczne-sa-w-polsce-najbardziej-potrzebne.

Strużyna, J. (2010). Ewolucja strategicznego zarządzania zasobami ludzkimi. Zarządzanie Zasobami Ludzkimi, 3 (4), 12-28.

Szczepaniak, M. (2014). Znaczenie sieci współpracy w rozwoju innowacji społecznych. Organizacja i Zarządzanie, 76, 155-166.

Sztompka, P. (2002). Socjologia. Analiza społeczeństwa. Kraków: Wydawnictwo Znak.

TEPSIE (2012). Defining social project, Part 1, Pobrano z: http://siresearch.eu/sites/default/files/1.1\%20Part\%201\%20-\%20defining\%20social\%20innovation_0.pdf.

Wronka-Pośpiech, M. (2015). Innowacje społeczne - pojęcie i znaczenie. Studia Ekonomiczne, 212, 124-136.

\section{DOKUMENTY}

European Commission (2012). Europejskie partnerstwo na rzecz innowacji sprzyjającej aktywnemu starzeniu się w dobrym zdrowiu 2012. Bruksela.

European Commission (2013a). Communication from the commission to the European Parliament, the council, the european economic and social committee and the committee of the regions. Towards Social Investment for Growth Cohesion - including implementing the European Social Fund 2014-2020, Brussels, COM 83/2013 final. Pobrano z: file://C:/Users/ ZSGiO\%20vb/Downloads/COMM_Social-investment-package_en\%20(2).pdf.

European Commission (2013b). Guide to Social Innovation. Regional and Urban Policy, Pobrano z: http://s3platform.jrc.ec.europa.eu/documents/20182/84453/Guide_to_Social_Innovation. pdf/88aac14c-bb15-4232-88f1-24b844900a66.

European Commission (2015). Social policy innovation. Meeting the social needs of citizens. Luxembourg.

Główny Urząd Statystyczny (2014). Ubóstwo ekonomiczne w Polsce w 2014 roku. Warszawa: GUS.

Główny Urząd Statystyczny (2016). Liczba bezrobotnych zarejestrowanych oraz stopa bezrobocia według województw, podregionów i powiatów. Warszawa: GUS.

Komisja Europejska (2011). Inicjatywa na rzecz przedsiębiorczości społecznej 2011. Bruksela.

Komisja Europejska (2014). Unia Innowacji. Badania, rozwój i innowacje. Bruksela.

Ministerstwo Pracy i Polityki Społecznej (2014). Krajowy Program Przeciwdziałania Ubóstwu i Wykluczeniu Społecznemu do 2020. Nowy wymiar aktywnej integracji. Warszawa.

Ministerstwo Spraw Wewnętrznych i Administracji (2010). Europejska Agenda Cyfrowa. Program rozwoju społeczeństwa informacyjnego w Unii Europejskiej w latach 2010-2015. Warszawa.

Organization for Economic Co-operation and Development (2011). Fostering innovation to address social challenges Committee for Scientific and Technological Policy (CSTP), Paris. Pobrano z: https://www.oecd.org/sti/inno/47861327.pdf. 


\section{KEYWORDS}

SOCIAL INNOVATIONS,

CIVIL SOCIETY,

COOPERATIVE NETWORKS,

TYPES OF SOCIAL

INNOVATIONS
SUMMARY The present-day society in Poland is more and more conscious of its responsibility for the economic and social life, especially at the local level. Civil society is not a passive re-ceiver of services, but it is an observer and a creator. Social innovations, with their main func-tion to solve social problems, make it possible to fully use the potential of civil society. Social innovations affect the areas inaccessible for the central government or the parliament. Social innovations have several advantages, which are difficult to quantify. Creating inter-sectoral partnerships, a closer cooperation at the local level, integration are just a few examples of these advantages brought by social innovations. Multi-dimensional effects of the innova-tions of that type, and first of all the ones that build up the social capital, are the argument for engaging the Polish society in that kind of activity. A possibility of financing innovations by the EU's funds and good practices in that area encourage to implement social innovations at the local and national levels. 